\title{
Screening of Fermentative Microorganisms with Amylolytic Potentials Involved in the Fermentation of Traditional Fermented Products in Togo
}

\author{
Essozimna Kogno ${ }^{1,2}$, Bouraïma Djeri ${ }^{1}$, Kokou Anani ${ }^{1}$, Kouassi Soncy ${ }^{1}$, \\ Simplice Damintoti Karou ${ }^{1}$, Yaovi Ameyapoh ${ }^{1}$ and Fatiou Toukourou ${ }^{2}$ \\ ${ }^{1}$ University of Lome, College of Biological and Food Technology (ESTBA), Laboratory of \\ Microbiology and Quality Control of Foodstuffs, BP 1515 Lomé, Togo \\ ${ }^{2}$ University of Abomey-Calavi, Faculty of Sciences and Techniques (FAST), Laboratory of \\ Microbiology and Food Technology, BP 526 Cotonou, Benin \\ *Corresponding author
}

\begin{tabular}{|l|}
\hline Ke y w o r d s \\
$\begin{array}{l}\text { Screening, Amylase } \\
\text { activity, Lactic acid } \\
\text { bacteria, Yeast, } \\
\text { Fermented foods, } \\
\text { Togo. }\end{array}$ \\
\hline Article Info \\
\hline $\begin{array}{l}\text { Accepted: } \\
\text { 18 February } 2017 \\
\text { Available Online: } \\
\text { 10 March } 2017\end{array}$ \\
\hline \hline
\end{tabular}

The transformation of cereals and tubers with amylolytic fermentation allows the conservation of foods and increase their energetic and nutritional values. The aim of this work was to search fermentative strains with amylolytic potentials. Isolation of microbial flora on 45 samples of fermented foods (agbelima, eblima and epoma) was performed. The search of microorganisms producing amylases was realized on appropriate culture media combined with $1 \%$ of soluble starch. The combination of morphologic and biochemical characters (API gallery) allowed to identify efficient isolates. Results showed that isolates were amylolytic with respectively $46.67 \%, 31.04 \%$ and $32 \%$ of lactic acid bacteria, yeast and mould compared to the total number of isolates. There were six strains having high amylolytic activity. These strains were identified as Lactobacillus fermentum, Lactobacillus plantarum, Candida guilliermondii, Candida krusei, Saccharomyces cerevisiae and Candida tropicalis. The development of starter culture from these microorganisms is important for the potential production of standardized fermented products at a commercial, small industrial scale, and for the improvement of their acceptability, microbiological stability and hygienic safety.

\section{Introduction}

The traditional cereal-based foods that are consumed in West Africa are processed by the natural fermentation of cereals and tubers and are particularly important as weaning foods for infants and as dietary staples for adults (Yao et al., 2009). The number of traditional fermented foods in the world is estimated to 3500 (Soomro et al., 2012). Lactic acid fermentation has been shown to improve flavor, shelf live, nutritional value or digestibility of fermented foods and alter food composition in such a way that it will require minimal energy both in cooking and preservation process (Nout, 1994). Lactic acid fermentation of amylaceous vegetables is very current southern countries (Oyewole, 1997). There exists a large variety of these lactic acid fermentation-based products. Among them, mawè/eblima, ogi, kenkey, uji, kisra, togwa, attiéké, gari, agbelima (Hounhouigan et al., 1993; Amoa-Awua et al., 1996; Yao et al., 2009; Kouame et al., 2013) can be cited. 
However, the traditional fermented based materials which are starchy raw slurry form are nutritionally inadequate because of their low energy density and their imbalance in macro and micronutrients. The healthy nutrition in developing countries is essential for infants and young children to have access to complementary foods with appropriate nutritional, bacteriological and organoleptic properties; culturally and economically acceptable, and promoting the way they can be feed (Lutter, 2003; Dewey and Brown, 2003). Previous studies (Agati et al., 1998; Djoulde et al., 2005; Songre-Ouattara et al., 2009) on these fermented foods allowed to isolates microorganisms known as amylolytic fermentative strains. Amylolytic lactic acid fermentation brings an improvement in digestibility of sugars, particularly starch (Haydersah, 2010). It also permits to improve the energetical and nutritional values of amylaceous porridges and reduces their stickiness by hydrolysis of sugars starch like glucose, fructose, saccharose, maltose and dextrins (Nguyen et al., 2007; Songre-Ouattara et al., 2009). During the fermentation of some amylaceous products, many amylolytic bacteria were isolated. Among them, Lactobacillus plantanum A6 (homolactic strain) from cassava retting (Giraud et al., 1991) and Lactobacillus fermentum OgiE1 (heterolactic strain) isolated from fermentation of bitter starch (Agati et al., 1998) can be cited. Agbelima, eblima and epoma, are fermented foods which are widely consumed in Togo (Ola, 2010). They are produced by traditional uncontrolled fermentation of Manihot esculenta Crantz, Zea mays and Sorghum bicolor respectively. Presently, there is a pressing need to improve the informal traditional food processing sector as a whole in the advent of fast foods which could out compete the indigenous foods. It is in this regard that a lot of other indigenous African fermented foods have become subjects of intense scientific studies. Such investigations provide a basis for injection of suitable scientific and technological know-how to upgrade the traditional operations and the quality of the indigenous foods. With regards to the presence of fermentatives strains particularly amylolytic in fermentation, there is very little information in the literature on them.

This work was carried out to screen fermentative microorganisms with amylolytic potentials involved in agbelima, eblima and epoma fermentation which could eventually lead to the development of a starter culture for its controlled fermentation during industrial production.

\section{Materials and Methods}

\section{Collection of fermented products samples}

The biological material used in this study was constituted by three different types of fermented products all drawn in five markets of Lomé, the capital of Togo, namely Adidogomé, Agoè-Assiyéyé, Akodésséwa, Gbossimè and Hanoukopé for searching micro-organisms having amylolytic potentials. Fifteen samples of $200 \mathrm{~g}$ of each product, three samples per market and summing up to 45 samples were drawn randomly at sale display. They were put in stomacher bags and quickly take away to the laboratory for analysis.

\section{Isolation of fermentative microorganisms}

Ten (10) g of sample were diluted with $90 \mathrm{ml}$ of Tryptone Salt before homogenization in a stomacher lab-blender for $3 \mathrm{~min}$. Decimal dilutions of the mixture were done up to $10^{-7}$ and then some appropriate dilutions were sown on appropriate agar culture media. Two categories of germ were isolated: yeasts and moulds on Sabouraud dextrose agar 
supplemented with $250 \mathrm{mg} / 100 \mathrm{ml}$ chloramphenicol and lactic acid flora on De Man Rogosa Sharpe agar. Yeasts and moulds searching were done following NF ISO 7954 standard (1988). Isolation of the lactic acid flora was realized according to the method previously described by Hounhouigan et al., (1993). After incubation, for each box of kneaded, characteristics colonies was purified by successive picking outs and preserved for further steps.

\section{Selection of amylolytic strains}

Amylolytic strains were isolated on MRS agar culture media combined with soluble starch at $1 \%$ for lactic acid flora and Potatoes Dextrose Agar culture media combined with soluble starch at $1 \%$ for yeasts and moulds (Djoulde et al., 2005). A mixture was obtained by putting a well individualized colony in $9 \mathrm{ml}$ of Müller Hinton broth, and then decimal dilutions up to $10^{-3}$ were carried out. A volume of $0.1 \mathrm{ml}$ of each dilution was spread on selection media. After incubation at $30^{\circ} \mathrm{C}$ during 24 to $72 \mathrm{~h}$, the surface of boxes was flooded with a Lugol's iodine and halo colonies were booked and considered as amylase producers (Olukoya, 1995). The appeared diameter of halo and the diameter of the corresponded colony were measured. The selection of strains was done according to the ratio of halo diameter around the colony (D1) by the diameter of the colony (D2) (Ameyapoh et al., 2006). The ratio D1/D2 is interpreted as follow: null activity: absence of halo around colonies, low activity: ratio D1/D2 in [1.01-1.50], average activity: ratio D1/D2 in [1.50-1.80] and high activity: ratio D1/D2 $\geq 1,80$.

\section{Effect of starch concentration on microbial growth and amylase synthesis}

In order to study the effect of starch concentration on amylolytic development and potential of selected microorganisms, five starch concentrations were tested: $1 \%, 2 \%$, $4 \%, 6 \%$ and $8 \%$. Culture from 16 to 18 hours is realized from pure colonies of each microorganism. These colonies are hanged in distilled water containing sodium chloride at 9 per thousand leading to have a turbidity similar to McFerland reference (0.5) whose microbial concentration correspond to $10^{8}$ UFC/ml. Aliquots of this abeyance $(0.1 \mathrm{ml})$ are sowed on MRS agar and PDA agar with growing soluble starch concentration. The counting, the measure of halo diameter appeared after vaporization of Lugol's iodine and the one of the corresponding colony is done after incubation.

\section{Phenotypic characters and identification of strains}

Gram staining, oxidase activity, catalase activity, production of acetoin and sporulation were biochemical tests performed. Cell morphology was determined with cells grown in MRS or PDA at $37^{\circ} \mathrm{C}$ for 16 hours by using optical microscopy with objectives X40 and X100 to see cell form, cellular arrangement and their mobility. $\mathrm{CO}_{2}$ and $\mathrm{H}_{2}$ production from glucose were performed using Kliger Iron Agar. Carbohydrate fermentation patterns were determined by the API $50 \mathrm{CH}$ and API 20C AUX as described by the manufacturer and the identification was done by a computerized database programme provided by the same manufacturer.

\section{Results and Discussion}

\section{Isolation of microbial flora}

A total of 281 strains of different groups of microorganisms were isolated from the 45 samples of agbelima, eblima and epoma and were divided as follow: 165 isolates of lactic acid flora, 91 isolates of yeasts and 25 isolates of moulds. These strains were tested for their capacity to produce amylases. 


\section{Selection of strains with amylolytic activity}

The description of the amylase activity of the 281 isolates revealed zones of lysis of various dimensions. Thus 161 isolates didn't present zones of lysis (null amylolytic activity), 75 isolates had ratio D1/D2 between 1.01 and 1.50 (low amylolytic activity), 39 isolates had ratio D1/D2 between 1.50 and 1.80 (average amylolytic activity) and 6 had a ratio D1/D2 $\geq$ 1.80 (high amylolytic activity). Table 1 showed the intensity of amylolytic activity of fermentatives isolates. Among amylase producer microorganisms, some presented interesting enzymatic potentialities. There was notably two (2) isolates on De Man Rogosa Sharpe agar coded LAA and LAB and four (4) isolates on Potatoes Dextrose Agar coded LEA, LEB, LEC and LED as showed in figure 1. The strains LAA and LEA presented the smallest ratio D1/D2 (1.82) and LED, the biggest ratio (3.18). In general, during these experiences, the best amylase synthesis was globally observed with yeasts than lactic acid strains.

\section{Effect of starch concentration on microbial growth}

The effect of starch concentration on the growth of strains that have high amylolytic activity was showed by figure 2. The microbial growth decreased when starch concentration increased for lactic isolates LAA and LAB and for yeast isolates LEA, LEB and LED. Regarding the LEC isolate, its charge increased when the starch concentration varied from $1 \%$ to $2 \%$ before decreasing progressively with increase of the starch concentration. The yeast strain coded LED has the greatest microbial loads at the concentrations of starch $1 \%$ to $6 \%$ and absence of culture to the concentration $8 \%$ while the other isolates presented a culture at $8 \%$.

\section{Amylase activity according to starch concentration}

Amylase activities (ratio D1/D2) of the 5 strains isolated from fermented products (LAA, LAB, LEA, LEB and LED) decreased when the starch concentration increased as illustrated in figure 3. Regarding the LEC strain, its amylolytic activity increased when the starch concentration varied from $1 \%$ to $2 \%$ before decreasing progressively with increase of the concentration. The isolate coded LED, LEC and LAA have respectively the best amylolytic activities with the starch concentration at $1 \%$, at $2 \%$ and $4 \%$ and at $4 \%$ and $6 \%$. The yeast isolate LEB didn't present amylolytic activity at $8 \%$ concentration of starch.

\section{Phenotypic characters and identification of outstanding isolates}

\section{Identification MRS agar isolates}

Morphological, physiological and biochemical characteristics of lactic isolates were listed in table 2. The physiological characteristics of bacteria (LAA, LAB) showed that both strains are Gram positive, catalase negative and oxidase negative. Examination of their shape and arrangement using a microscope at $\times 40$ showed that the strains (LAA, LAB) cells were rod-shaped arranged in small chain.

After studying morphological, physiological and biochemical characteristics, identification was completed using ferment properties of isolates on API $50 \mathrm{CH}$ gallery, containing 49 sugars. Based on their assimilation of carbon compounds, the lactic acid isolates LAA and LAB were respectively identified as Lactobacillus fermentum and Lactobacillus plantarum. 
Table.1 Number of isolates of each germ by amylolytic activity intensity

\begin{tabular}{|c|c|c|c|c|}
\hline \multirow{2}{*}{ Microorganisms } & \multicolumn{4}{|c|}{ Number of isolates with amylolytic activity } \\
\cline { 2 - 5 } & Null & Low & Average & High \\
\hline Lactic acid flora & 88 & 44 & 31 & 02 \\
\hline Yeasts & 56 & 23 & 08 & 04 \\
\hline Moulds & 17 & 08 & 00 & 00 \\
\hline Total & 161 & 75 & 39 & 06 \\
\hline
\end{tabular}

Table.2 Morphological and biochemical Characteristics of lactic isolates

\begin{tabular}{|c|c|c|}
\hline \multirow{2}{*}{ Characters } & \multicolumn{2}{|c|}{ Strains } \\
\hline & LAA & LAB \\
\hline Aspect & $\begin{array}{c}\text { White and smooth } \\
\text { colonies/Type } S\end{array}$ & $\begin{array}{c}\text { White and smooth } \\
\text { colonies/Type S }\end{array}$ \\
\hline Shape & Rod & Rod \\
\hline Grouping & Small chain & Small chain \\
\hline Gram & Gram + & Gram + \\
\hline Catalase & - & - \\
\hline Oxidase & - & - \\
\hline Sporulation & - & - \\
\hline Urea & - & - \\
\hline VP & - & + \\
\hline Indole & - & - \\
\hline Citrate & - & + \\
\hline Grow that $10^{\circ} \mathrm{C}$ & + & + \\
\hline Grow that $30^{\circ} \mathrm{C}$ & + & + \\
\hline Grow that $45^{\circ} \mathrm{C}$ & + & + \\
\hline Grow that $\mathrm{pH} 4.5$ & + & + \\
\hline Grow that $\mathrm{pH} 6.5$ & + & + \\
\hline Grow that $2 \% \mathrm{Na}$ & + & + \\
\hline Grow that $4 \% \mathrm{Na}$ & - & - \\
\hline Resistance at $60^{\circ} \mathrm{C}$ & + & + \\
\hline Esculine & + & + \\
\hline Mannitol & + & + \\
\hline Glucose & + & + \\
\hline Lactose & - & - \\
\hline Gas & - & - \\
\hline $\mathrm{H}_{2} \mathrm{~S}$ & - & - \\
\hline Suspected genus & Lactobacillus sp. & Lactobacillus sp. \\
\hline
\end{tabular}

Legend:(+) positive reaction; (-) negative reaction; VP: reaction of Vogues-Proskauer 
Table.3 Morphological and biochemical characteristics

\begin{tabular}{|c|c|c|c|c|}
\hline \multirow{2}{*}{ Characteristics } & \multicolumn{4}{|c|}{ Strains } \\
\hline & LEA & LEB & LEC & LED \\
\hline Macroscopic & $\begin{array}{c}\text { Waxy, rounded } \\
\text { and white } \\
\text { colony }\end{array}$ & $\begin{array}{l}\text { Waxy, rounded } \\
\text { and broken white } \\
\text { colony }\end{array}$ & $\begin{array}{l}\text { Smooth, flat } \\
\text { and cream } \\
\text { colony }\end{array}$ & $\begin{array}{l}\text { Waxy, rounded } \\
\text { and white colony }\end{array}$ \\
\hline Microscopic & $\begin{array}{l}\text { Thallus and } \\
\text { partitioned cell } \\
\text { with a simple } \\
\text { fragmentation of } \\
\text { mycelium }\end{array}$ & $\begin{array}{c}\text { Thallus and } \\
\text { partitioned cell } \\
\text { with a simple } \\
\text { fragmentation of } \\
\text { mycelium }\end{array}$ & $\begin{array}{c}\text { Ovoid cell of } \\
\text { multilateral } \\
\text { budding with a } \\
\text { pseudo- } \\
\text { mycelium }\end{array}$ & $\begin{array}{c}\text { Thallus and } \\
\text { partitioned cell } \\
\text { with a simple } \\
\text { fragmentation of } \\
\text { mycelium }\end{array}$ \\
\hline Glucose & + & + & + & + \\
\hline Galactose & + & - & + & + \\
\hline Maltose & + & - & + & + \\
\hline Saccharose & + & - & + & - \\
\hline Raffinose & + & - & + & - \\
\hline Sorbitol & + & - & + & + \\
\hline Celobiose & + & - & - & - \\
\hline Inositol & - & - & - & - \\
\hline Hyphes & - & + & - & + \\
\hline DBB test & - & - & - & - \\
\hline Suspected genus & Candida & Candida & Saccharomyces & Candida \\
\hline
\end{tabular}

Legend:(+) Positive reaction; (-) Negative reaction; $\mathrm{DBB}=$ Diazonium Blue $\mathrm{B}$

Figure.1 Ratio D1/D2 of outstanding strains

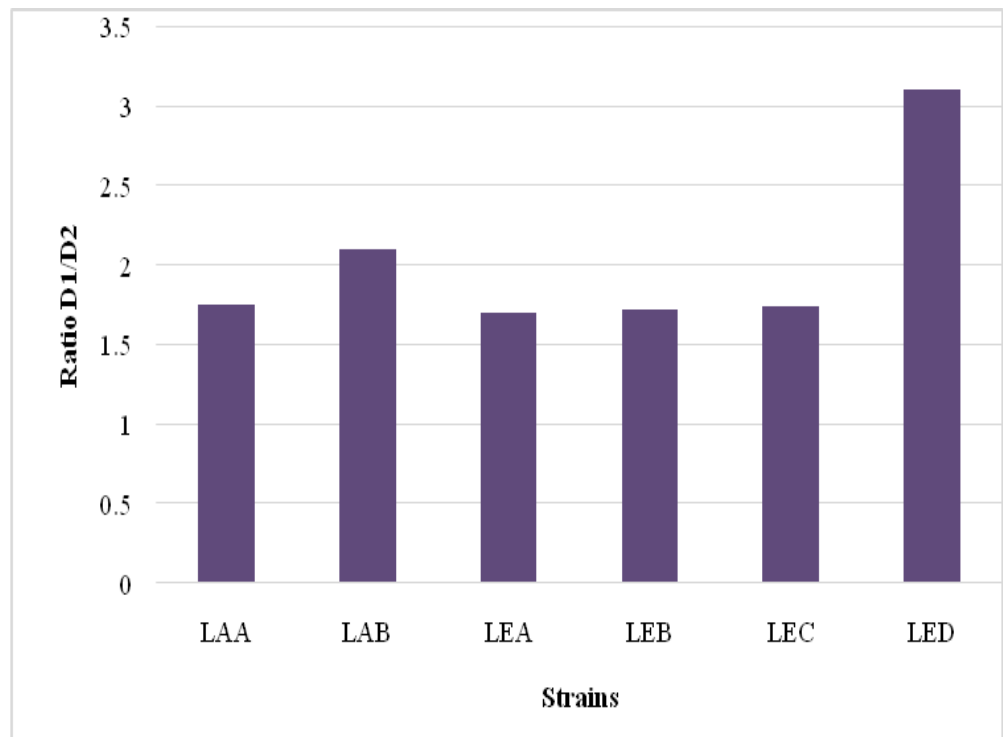


Figure.2 Effect of starch concentration on growth of isolates

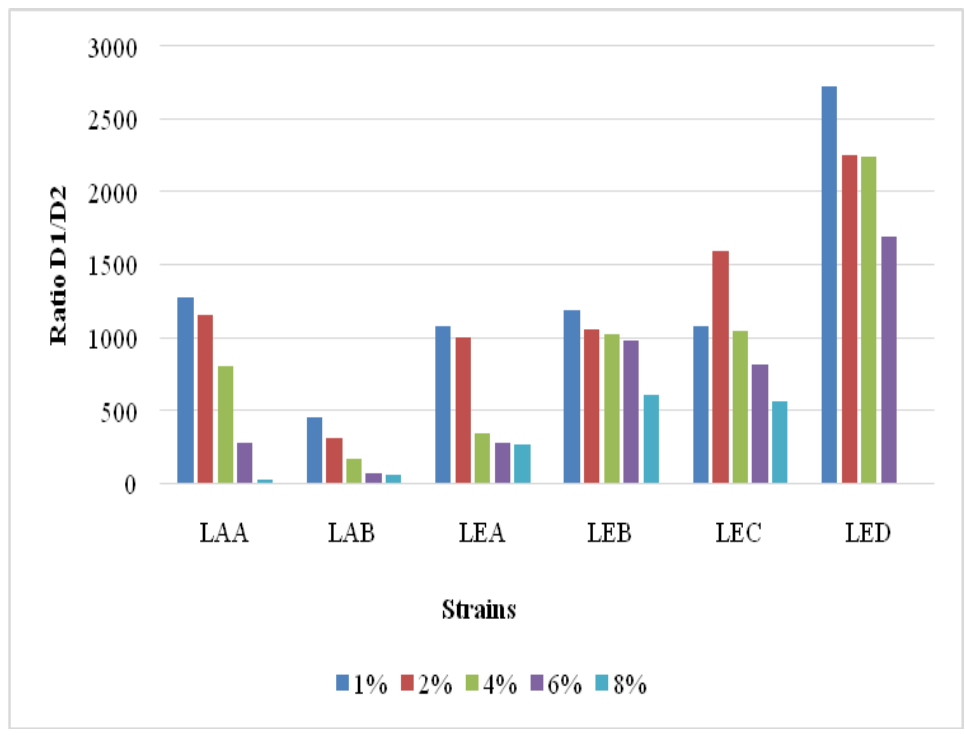

Figure.3 Effect on starch concentration on amylolytic activity of isolates

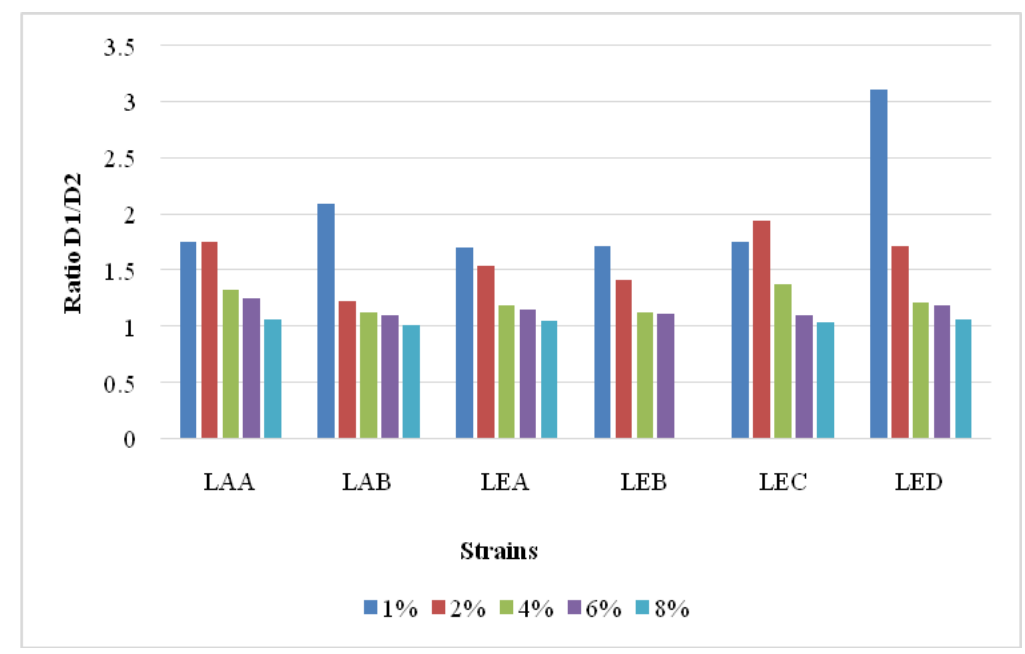

Identification of isolates of sabouraud agar with chloramphenicol

Table 3 listed biochemical and morphological characteristics of LEA, LEB, LEC and LED that have high amylolytic activity. After preliminary microscopic confirmation all 4 yeasts were subjected to morphology, fermentation and assimilation tests. None of the isolates could ferment inositol whereas the majority fermented glucose $(100 \%)$, maltose $(75 \%)$ and raffinose $(50 \%)$. All isolates were ascomycetous yeasts as revealed by
Diazonium Blue B test. Based on their assimilation of carbon compounds, the isolates LEA, LEB, LEC and LED were identified being respectively Candida guilliermondii, Candida krusei, Saccharomyces cerevisiae and Candida tropicalis.

\section{Isolation of fermentative microorganisms}

This work aims to screen fermentatives micro-organisms with amylolytic potentials of agbelima, eblima and epoma, three fermented 
foods in Togo obtained respectively from cassava, maize and millet. Microbiological analysis of different products coming from five markets of Lomé reveals the presence of lactic acid flora, yeasts and moulds. These results are the same found by Hounhouigan et al., (1993) and N'tcha et al., (2015) who reported that lactic acid bacteria and yeasts are predominant micro-organisms in most of native African fermented foods. According to Amoa-Awua et al., (1996) and Assanvo et al., (2006), lactic acid bacteria and yeasts isolated of fermented amylaceous products are only ferment germs. Also, moulds also take part in the process of fermentation. Indeed, Djoulde et al., (2005) findings revealed the presence of moulds in fermented foods from cassava.

\section{Selection of strains with amylolytic activity}

The isolates were tested to see their capacity to produce amylases. Globally, they were amylolytic with respectively $46.67 \%$ of lactic acid isolates, $31.04 \%$ of yeast isolates and $32 \%$ of moulds isolates. This reveals the high proportion of micro-organisms that produce amylases. Indeed, there exists a high correlation between natural starched substrates and presence of amylolytic microorganisms during fermentation of these substrates (Haydersah, 2010). According to Yao et al., (2009), the high proportion of amylolytic micro-organisms could be linked to the rate of starch in analysed products (more than $80 \%$ of dry matters).In consideration of the richness of raw materials, essentially composed of starch, it is not surprising that almost all tropical amylaceous fermented foods contain amylolytic microorganisms with rates from $12 \%$ to $14 \%$ (Haydersah, 2010). These rates can vary during the fermentation. Thus, for pozolmexican the proportion of amylolytic micro-organisms in bacterial community varies approximately from $40 \%$ to $30 \%$ at the beginning and the end of fermentation (Diaz-
Ruiz et al., 2003). The presence of amylase activity during fermentation has been previously mentioned by Tou et al., 2006 and Songre-Ouattara et al., 2009. Tou et al., (2006) indicated during the production of ben-saalga, its micro-flora was dominated by lactic acid bacteria with ratio amylolytic bacteria/bacteria at $12 \%$. This result is clearly lower than the ratio obtained during this work (ratio amylolytic bacteria/bacteria at $46.67 \%$ ). The difference could be explained by the nature of samples, the duration of fermentation and the type of technology used for the production of ferments.

\section{Effect of starch concentration on microbial growth and amylase activity}

Analysis of the effect of starch concentration on the growth and amylase activity of isolates shows globally that the utilization of starch at concentration $1 \%$ favours microbial growth and induces amylase synthesis of the studied isolates. The effect of starch concentration on bacterial development was also studied by Lagzouli et al., (2007). The study of amylase activity depending on starch concentration reveals that utilization of starch at $1 \%$ concentration induces the production of amylase. This result is in concordance with Bennamoun et al., (2004) who showed that starch at $0.8 \%$ is the best inductor of $\alpha$ amylase of Aspergillus oryzae and that the synthesis of enzyme decreased when the substrate concentration decreases. The decrease of starch synthesis is probably due to the increase of glucose level accumulated during the hydrolysis of starch with repression of the synthesis of amylases. Besides, starch, maltose and another saccharide are described like inductors of amylases (Moreira et al., 2001). Nevertheless, sometimes when the concentrations are very large, they are easily hydrolysed in glucose and the production of enzyme is negatively affected (Ray et al., 1996). 
Phenotypic characters and identification of outstanding isolates

Previous study on traditional fermented foods in Benin mentioned the presence of amylolytic lactic acid bacteria in fermented foods from maize, sorghum and millet (Tchekessi et al., 2014). Another research (Songre-Ouattara et al., 2009) on fermentation of millet indicates that lactic acid bacteria of Lactobacillus genera are known for their production of amylolytic enzymes. Djoulde et al., (2005) identified strains of Lactobacillus of which Lactobacillus cellobiosus, Lactobacillus sake, Lactobacillus coprophilus, Lactobacillus plantarum, Lactobacillus fermentum, Lactobacillus alimentarus and Lactobacillus acidophilus like species of amylolytic lactic acid bacteria involved in the fermentation of cassava. Kermiche (2013) during the characterization of some microbial strains involved in fermented wheat revealed that germs of Saccharomyces genera have a high amylolytic activity. Djoulde et al., (2005) added that $67 \%$ of yeasts isolated during the fermentation of cassava have $\alpha$-amylase activity and are in majority composed of Saccharomyces and Candida genera. Amylolytic micro-organisms used in the fermentation permits to improve the energetical and nutritional values of amylaceous porridges and reduce their viscosity (Nguyen et al., 2007).

In conclusion, the present findings show the detailed information and further expansion on the state of knowledge about amylolytic micro-organisms in agbelima, eblima and epoma, three fermented foods in Togo. This research permitted to test the capacity of 281 isolates to produce amylases. Indeed, six isolates are revealed to have attractive enzyme potentials. That is: Lactobacillus fermentum, Lactobacillus plantarum, Candida guilliermondii, Candida krusei,
Saccharomyces cerevisiae and Candida tropicalis. This experiment confirmed that the substrate concentration greatly influences the amylase activity of strains. Lactic acid fermentation of vegetable matters is a promising process to bring into focus some new fermented foods that have better added value with poor cost. These preliminary results could contribute to bring into focus a starter for fermentation of local amylaceous foods in order to have innovative goods having satisfactory energizing and nutritional value.

\section{References}

Agati, V., J.P. Guyot, J. Morlon-Guyot, P. Talamond and Hounhouigan, D. 1998. Isolation and characterization of new amylolytic strains of Lactobacillus fermentumfrom fermented maize doughs (mawè and ogi) from Benin. J. Appl. Microbiol., 85(3): 512-520.

Ameyapoh, Y., K. Wokpor and de Souza, C. 2006. Identification et sélection de souches de levure performantes pour la production d'alcool. J. des Sci., 6(1): 30-40.

Amoa-Awua, W.K.A., F.E. Appohand Jakobsen, M. 1996. Lactic acid fermentation of cassava dough into agbelima. Int. J. Food Microbiol., 31(13): 87-98.

Assanvo, J.B., G.N. Agbo, Y.E.N. Behi, P. Coulinand Farah, Z. 2006. Microflora of traditional starter made from cassava for "attiéké" production in Dabou (Côte d'Ivoire). Food Control, 7(1): 37-41.

Bennamoun, L., Z. Meraihi and Dakhmouche, S. 2004. Utilisation de la planification expérimentale pour l'optimisation de la production de l'a-amylase par Aspergillus oryzae Ahlburg (Cohen) 1042.72 cultivée sur un milieu à base de déchets d'oranges. J. Food Engi., 64(2): 257-264. 
Dewey, K.G., and Brown, K.H. 2003. Update on technical issues concerning complementary feeding of young children in developing countries and implications for intervention programs. Food and Nutrition Bull., 24(1): 5-28.

Diaz-Ruiz, G., J.P. Guyot, F. Ruiz-Teran, J. Morlon-Guyot and Wacher, C. 2003. Microbial and Physiological Characterization of Weakly Amylolytic but Fast-Growing Lactic Acid Bacteria: a Functional Role in Supporting Microbial Diversity in Pozol, a Mexican Fermented Maize Beverage. Appl. Environ. Microbiol., 69(8): 4367-4374.

Djoulde, D.R., F.X. Etoa, J.J. Essia-Ngang and Mbofung, C.M.F. 2005. Screening des microorganismes à potentialités fermentaires pour le manioc. Tropicultura, 23(1): 11-18.

Giraud, E., A. Brauman, S. Keleke, B. Lelong and Raimbault, M. 1991.Isolation and physiological study of an amylolytic strain of Lactobacillus plantarum. Appl. Microbiol. Biotechnol., 36(3): 379-383.

Haydersah, J. 2010. Etude de la fermentation lactique de plantes amylacées tropicales, potentiel des bactéries lactiques amylolytiques. Thèse de doctorat, Université des Antilles et de la Guyane, Guadeloupe, France.

Hounhouigan, D.J., M.J.R. Nout, C.M. Nago, J.H. Houben and Rombouts, F.M. 1993. Characterisation and frequency distribution of species of lactic acid bacteria involved in the processing of mawè, a fermented maize dough from Benin. Int. J. Food Microbiol., 18(4): 279-287.

Kermiche, M. 2013. Caractérisation de certaines souches microbiennes évoluant dans le blé fermenté et mise en évidence de leurs activités enzymatiques. Thèse de Magister, Université Constantine 1, Constantine, Algérie.

Kouame, A.K., T.N. Djeni, F.K. N'guessan and Dje, M.K. 2013. Post-processing microflora of commercial attieke (a fermented cassava product) produced in the south of Côte d'Ivoire. Lett. Appl. Microbiol., 56(1): 44-50.

Lagzouli, M., Z. Mennane, A. Aitounejjar, Y. El Kettani, M. Elyachoui, M. Ouhssine, E.H. Berny and Jadal, M. 2007. Optimization of composition of media for the production of extracellular glucoamylase by Candida guilliermendii. Pak. J. Biol. Sci., 10(19): 3322-3329.

Lutter, C.K. 2003. Macrolevel approaches to improve the availability of complementary foods. Food and Nutri. Bull., 24(1): 83-103.

Moreira, F.G., V. Lenartovicz, C.G.M. Souza, E.P. de Ramos and Peralta, R.M. 2001. The use of $\alpha$-methyl-D-glucoside, a synthetic analogue of maltose, as inducer of amylase by Aspergillus sp. in Solid-state and submerged fermentations, Brazilian J. Microbiol., 32(1): 15-19.

N'tcha, C., G. Vieira-Dalode, B.P. Agbobatinkpo, A.P.P. Kayode, A.D. Adeyemi, J.T.C. Codjia and BabaMoussa, L. 2015. Caractérisation physicochimique et microbiologique du " kpètè-kpètè », un ferment des bières traditionnelles produites au Bénin. Annales des sciences agronomiques, 19(2): 69-88.

Nguyen, T.T.T., G. Loiseau, C. IcardVerniere, I. Rochette, S. Treche and Guyot, J.P. 2007. Effect of fermentation by amylolytic lactic acid bacteria, in process combinations, on characteristics of rice/soybean slurries: A new method for preparing high energy density complementary foods for young children. Food Chem., 100(2): 623-631.

Norme Française ISO 7954. 2003. Directives générales pour le dénombrement des levures et moisissures, techniques par 
comptage des colonies à $25^{\circ} \mathrm{C}$.

Nout, M.J.R. 1994. Fermented foods and food safety. Food Res. Int., 27(1): 291-298.

Ola, F. 2010. Contribution à l'établissement de la typologie microbiologique des produits fermentés de l'Afrique de l'ouest: cas du Togo, du Bénin, du Burkina-Faso et du Nigeria. Mémoire d'Ingénieur Agro-alimentaire, Université de Lomé, Lomé, Togo.

Olukoya, D.K. 1995. Screening of local isolate of Lactobacillus for characters useful in African food fermentations, In: Agbor, E.T., A. Brauman, D. Griffon and Trèche S. (Ed.), Transformation alimentaire du manioc, ORSTOM Press, Paris., pp.345-352.

Oyewole, O.B. 1997.Lactic fermented foods in Africa and their benefits, Food Control, 8(5-6): 289-297.

Ray, R.R., S.C. Jana and Nanda, G. 1996. Induction and catabolite repression in the biosynthesis of $\alpha$-amylase by Bacillus megaterium B6, Int. J. Biochem. Mol. Biol., 38: 223- 230.

Songre-Ouattara, L., C. Mouquet-Rivier, C. Icard-Vernière, I. Rochette, B. Diawara and Guyot, J.P. 2009. Potential of amylolytic lactic acid bacteria to replace the use of malt for partial starch hydrolysis to produce African fermented pearl millet gruel fortified with groundnut. Int. J. Food Microbiol., 30(3): 258-264.

Soomro, A., T. Masud and Kiran, A. 2002. Role of lactic acid bacteria (LAB) in food preservation and human health-a review, Pak. J. Nutri., 1(1): 20-24.

Tchekessi, C.K.C., I.Y. Bokossa, P. Azokpota, C. Agbangla, G. Daube, M.L. Scippo, N. Korsak, V. Gotcheva, G. Blagoeva and Angelov, A. 2014. Isolation and Quantification of Lactic Acid Bacteria from Traditional Fermented Products in Benin. Int. J. Curr. Microbiol. Appl. Sci., 3(11): 1-8.

Tou, E., J.P. Guyot, C. Mouquet-Rivier, I. Rochette, E. Counil, A. Traoré and Trèche, S. 2006. Study through surveys and fermentation kinetics of the traditional processing of pearl millet (Pennisetum glaucum) into ben-saalga, a fermented gruel from Burkina Faso. Int. J. Food Microbiol., 06(1): 52-60.

Yao, A.A., M. Egounlety, L.P. Kouame and Thonart, P. 2009. Les bactéries lactiques dans les aliments ou Boissons amylacés et fermentés de l'Afrique de l'Ouest : leur utilisation actuelle. Annales de Médecine Vétérinaire, 153: 54-65.

\section{How to cite this article:}

Essozimna Kogno, Bouraïma Djeri, Kokou Anani, Kouassi Soncy, Simplice Damintoti Karou, Yaovi Ameyapoh and Fatiou Toukourou. 2017. Screening of Fermentative Microorganisms with Amylolytic Potentials Involved in the Fermentation of Traditional Fermented Products in Togo. Int.J.Curr.Microbiol.App.Sci. 6(3): 1067-1077. doi: https://doi.org/10.20546/ijcmas.2017.603.123 